\title{
AUGMENTATION OF AGROMETEOROLOGICAL STATIONS NETWORK IN SOUTHERN LUZON, PHILIPPINES
}

\author{
Alejandro Amin Jalil ${ }^{1}$ \\ ${ }^{1}$ Basilan State College, \\ College of Agriculture and Fisheries, \\ Sta.Clara Campus, Lamitan City, \\ Basilan, \\ Philippines,
}

\section{Lea Soriano Caguiat ${ }^{2}$}

\author{
Kay Thi Khaing ${ }^{3}$ \\ ${ }^{3}$ Yezin Agricultural University, \\ Nay Pyi Taw, \\ Myanmar

\section{Bernalyn Mabli Alos 4} \\ Noreen Alguin Moreno ${ }^{5}$
}

Article DOI: https://doi.org/10.36713/epra6384

\begin{abstract}
The Philippines is always visited by typhoons every year which the southern Luzon area is a usual entry point. The study purposely to identify the most suitable locations of additional and to analyze the best sites for agrometeorological stations, their densities, and proper distribution inside the study area. The criteria for designing an augmented station based on World Meteorological Organization (WMO, 2010). The considerations and criteria for citing additional stations in the region are the followings: a) first approximation of admissible distance from existing weather stations; b) agricultural areas; c) climate type; d) slope (within 0-3\%); e) distance from water bodies, coastline, and roads. The use of GIS map analysis conforming with all of the designed criteria gave 34 additional weather stations installed in Southern Luzon to augment the existing stations. Therefore, by the addition of 34 stations, the weather information could forecast more accurately and more effectively.
\end{abstract}

KEYWORDS: Southern Luzon, Agrometeorological station, weather forecast

\section{INTRODUCTION}

The Philippines has a humid equatorial or tropical maritime climate. Its climates influence by the complex interaction of various factors such as geography and topography, principal air streams, ocean currents, linear systems such as the intertropical convergence zone, and tropical cyclones. These are factors that highly influence the agricultural development of the country. It recognized that weather stations including agrometeorological which play a vital role in the dissemination of precise weather information and to 
reduce the impact of meteorological hazards improving capability of disaster prevention and mitigation through providing early warning on severe weather such as typhoons, storms, rainstorms, lightning strikes, squall line winds, as well as line pollution flashover. According to the World Meteorological Organization (WMO, 2010), agrometeorological stations categories depending on their specific purposes within their territory. In general, most of the agrometeorological stations provide meteorological and biological information on weather analyses, forecasts, warnings related to the climatic regime on local agriculture. Therefore, the stations can provide detailed measurements in the very lowest layer of the atmosphere, the soil temperature and moisture, potential evapotranspiration, duration of vegetative wetting, phenology, onset and spread of plant diseases, and so forth. The agrometeorological station plays in the successful implementation of various research and development programs and for sustainable crop production as a significant role (Powell and Reubgard 2016, cited by Alejo, 2018).

For accurate observations at a given time and a true representation of the existing agricultural areas, all agrometeorology stations should be located in farming regions performing with a specific purpose and be dense enough to function as a network station (WMO, 2010). The appropriate distribution of agrometeorology stations can increase the effectiveness of the observations and provide accurate analysis results of the data. According to the WMO Technical Notes, the number of stations within each region should depend on its extent, climatic types and sub-types, and the spatial variations of such factors as the natural vegetation, main crops, and agricultural methods.

The most appropriate sites of agrometeorological stations are necessary to determine the economic, sociological, environmental, and technical sustainability of the project. Gubler et al. (2017) stated that improper siting of the weather stations is one of the sources for inaccuracies in gathering weather data. Systems (GIS) is an important support tool in decisionmaking that has the capability of operating and analyzing a great variety of spatial data in the determination of suitable AWS sites (Sener et al., 2012). GIS technology is an essential tool used to combine various map and satellite information sources in models that simulate complex natural systems (Rana, 2012). In the Philippines, climate and weather conditions such as typhoons have a destructive effect on the agricultural and industrial development of the country. Unfortunately, the existing station networks are not sufficient to be able to observe the weather data that contributes to the forecasting of the path of the typhoons and other relevant weather information; therefore, the study aim to identify the most suitable locations of additional and to analyze the best sites of agrometeorological stations, their densities and proper distribution inside the study area.

\section{MATERIALS AND METHODS}

\subsection{Geographical area description}

Luzon is the oldest and largest oceanic island in the Philippine archipelago (Vallejo,2014). It comprises three sections: Northern, Central, and Southern Luzon (including the National Capital Region). Southern Luzon is composed of a series of peninsulas trending southeast for about $150 \mathrm{~km}$. This portion of Luzon includes the National Capital Region (NCR), CALABARZON (Region IV-A), MIMAROPA (Region IV-B), Region 5 (Bicol Region). NCR comprises 16 cities called Metropolitan Manila, the capital region of the Philippines. It is located in the southwestern portion of Luzon and directly below Central Luzon. Region IV-A is in Southwestern Luzon, South, and East of Metro Manila. Its five provinces: Cavite, Laguna, Batangas, Rizal, and Quezon. Region IV-B covers five states: Marinduque, Occidental Mindoro, Oriental Mindoro, Palawan, and Romblon. MIMAROPA is an acronym combination of the Region's constituent provinces; Mindoro (divided into Occidental and Oriental Mindoro), Marinduque, Romblon, Palawan. It has no land border with another region. Region $\mathrm{V}$ compost of six provinces: Albay, Camarines Norte, Camarines Sur, Sorsogon, and the island-provinces of Catanduanes and Masbate. Southern Luzon has a total area of 61,687.98 square kilometers (23817.86 square miles).

\subsection{Determination of the location of existing weather station}

The locations of existing stations with their specific types and functions are maintained. For standardization purposes, only weather stations managed by the Philippines Atmospheric Geophysical and Astronomical Service Administration (PAGASA) included in the analysis. Project-based weather stations within the area were difficult to access for functionality and data availability. Automatic weather stations (AWSs), either government (project-based) or privately owned, were also excluded for suitability mapping due to similar reasons.

\subsection{Suitability criteria}

The criteria for designing an augmented station network in Southern Luzon are based on the guidelines for planning a meteorological station network set by the World Meteorological Organization (WMO, 2010). The considerations and criteria for citing additional stations in the region are the followings: a) first approximation of admissible distance from existing weather stations; b) agricultural areas; c) climate type; d) slope (within 0 - 
$3 \%)$; e) distance from water bodies, coastline, and roads. The details of these considerations and criteria are summarized in Table 1.

The recommended distance between stations on the reference station of the network of meteorological stations belongs to the first group but are serving two purposes-study of long-term climatic changes and correction of data from other stations. These stations should possess the longest possible observational series, should not be relocated, and the allowable distance between stations is 300 to $400 \mathrm{~km}$ (flat areas).

The digital elevation model (DEM), 30x30 meters resolution, Landuse/Landcover (LULC), and inland water bodies and coastlines sourced from National Mapping and Resource Information Authority (NAMRIA), Philippines. The road networks downloaded from Open street map data files available for the Philippines (Geofabrik, 2018). Location and status of existing weather stations, the climate type (based on Modified Corona's Classification of Climate) of the provinces of Southern Luzon, were based on the data released by Philippine Atmospheric, Geophysical, and Astronomical Services Administration (PAGASA).
The climate type base map is sourcing from NAMRIA. Most PAGASA Agromet stations in the country are usually in collaboration with State Universities and Colleges (SUCs). Likewise, additional weather forecasting centers for agricultural purposes should also collaborate with SUCs. The final selected suitable areas resulting from the overall criteria that beyond a $5 \mathrm{~km}$ radius from the center of the collaborating institutions are excluded. The reason is the ease of management and maintenance by the SUC with the justification that the off-campus weather station will be part of its extension campus. Weather stations reach a $30 \mathrm{~km}$ up to $50 \mathrm{~km}$ radius (Bermudez et al., 2017). Hence, for the analysis, the minimum $30 \mathrm{~km}$ radius of influence is used. The distance of additional stations from water bodies and coastlines is $100 \mathrm{~m}$ (WMO, 2010). The road buffer distance on the accessible distance for flat terrain is estimated to be $500 \mathrm{~m}$ (Tardin, 2013). For ease of management and maintenance, a distance of additional stations from collaborating institutions set to a $5 \mathrm{~km}$ radius with justification. The minimum area of the proposed additional stations set to $2000 \mathrm{~m}^{2}$.

Table 1. Suitability criteria for an augmented network of stations in Southern Luzon

Factor

First approximation of admissible distance between existing weather stations

\begin{tabular}{lll}
\hline Agricultural production areas & Suitable agricultural production areas & $\begin{array}{l}\text { Landuse/Landcover (LULC) } \\
\text { shapefile }\end{array}$ \\
\hline Climate type & $\begin{array}{l}\text { Modified Coronas Classification (MCC) Climate type shapefile } \\
\text { of Climate }\end{array}$ \\
\hline Slope & Within 0 to $3 \%$ & Digital elevation model (DEM) \\
\hline $\begin{array}{l}\text { Distance from water bodies and } \\
\text { coastline }\end{array}$ & Outside $100 \mathrm{~m}$ buffer & $\begin{array}{l}\text { LULC, water bodies, and } \\
\text { coastlines shapefile }\end{array}$ \\
\hline $\begin{array}{l}\text { Distance from roads } \\
\begin{array}{l}\text { Possible collaborating } \\
\text { institutions }\end{array}\end{array}$ & Ro0 m buffer & Road network shapefile \\
\hline
\end{tabular}

\subsection{Geographical (Map) Analysis}

Geographical (map) analysis done using a Geographic information system (GIS). The QGIS software is a free and open-source cross-platform desktop geographic information system application that supports viewing, editing, and analysis of geospatial data. The map generated using the different suitability criteria for an augmented network of stations was overlaid with all existing weather stations in Southern Luzon. The type of the proposed additional stations identified. Justifications as to why they need to include in the final augmented network of stations. The GIS mapping framework and procedure for the generation of suitability maps are illustrated in Figure 1. 


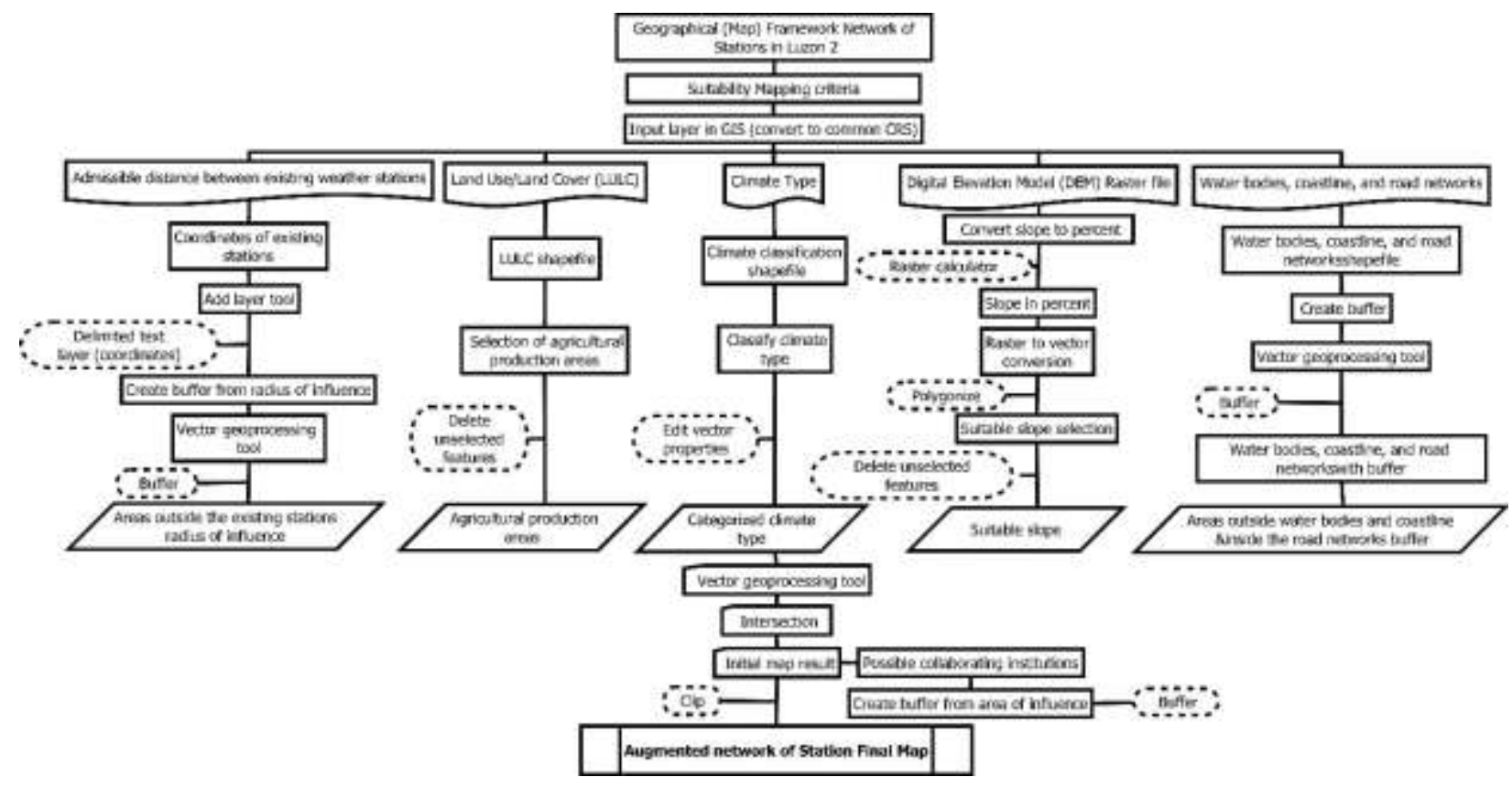

Figure 1. GIS Mapping Framework

\section{RESULTS AND DISCUSSION}

\subsection{Location of existing weather station}

Existing weather stations identified were stations with categories of synoptic and Agromet only. Other such as airport complex stations and radar stations are excluded because these give weather data, information, and advice for aviation activities and typhoon purposes only. There are 30 functional stations identified within Southern Luzon. The existing weather stations with their station category are summarized in Table 2 .

Table 2. Existing weather stations in Southern Luzon

\begin{tabular}{|c|c|c|}
\hline Region & Location & Type of Station \\
\hline NCR & NAIA Pasay City, Metro Manila & Synoptic Station \\
\hline NCR & Port Area, Manila & Synoptic Station \\
\hline NCR & Science Garden Quezon City, Metro Manila & Synoptic Station \\
\hline NCR & National Agromet Research Station-Metro Manila & Agromet Station \\
\hline $4 a$ & Alabat, Quezon & Synoptic Station \\
\hline $4 a$ & Ambulong Tanauan, Batangas & Synoptic Station \\
\hline $4 \mathrm{a}$ & Infanta, Quezon & Synoptic Station \\
\hline $4 a$ & Tayabas City, Quezon & Synoptic Station \\
\hline $4 a$ & Tanay, Rizal & Synoptic/Agromet station \\
\hline $4 \mathrm{a}$ & Sangley Point, Cavite & Synoptic Station \\
\hline $4 a$ & Cavite State University-Indang, Cavite & Agromet Station \\
\hline $4 a$ & Tagaytay City, Cavite & Agromet Station \\
\hline $4 \mathrm{a}$ & Bureau of Soil-Cuyambay Tanay, Rizal & Agromet Station \\
\hline $4 \mathrm{a}$ & Rizal Agricultural Station-Cuyambay Tanay, Rizal & Agromet Station \\
\hline $4 a$ & UPLB NAS-Los Baños, Laguna & Agromet Station \\
\hline $4 \mathrm{~b}$ & Calapan, Oriental Mindoro & Synoptic Station \\
\hline $4 \mathrm{~b}$ & San Jose, Occidental Mindoro & Synoptic Station \\
\hline $4 \mathrm{~b}$ & Coron, Palawan & Synoptic Station \\
\hline
\end{tabular}




\begin{tabular}{|c|c|c|}
\hline $4 \mathrm{~b}$ & Cuyo, Palawan & Synoptic Station \\
\hline $4 \mathrm{~b}$ & Puerto Princesa City, Palawan & Synoptic Station \\
\hline $4 \mathrm{~b}$ & Romblon City, Romblon & Synoptic Station \\
\hline $4 \mathrm{~b}$ & PNAC-Aborlan, Palawan & Agromet Station \\
\hline 5 & Daet, Camarines Norte & Synoptic Station \\
\hline 5 & Juban, Sorsogon & Synoptic Station \\
\hline 5 & Legazpi City, Albay & Synoptic Station \\
\hline 5 & Masbate City, Masbate & Synoptic Station \\
\hline 5 & Virac, Catanduanes & Synoptic Station \\
\hline 5 & BUCAF-Guinobatan, Albay & Agromet Station \\
\hline 5 & CBSUA-Pili, Camarines Sur & Agromet Station \\
\hline 5 & Parapoto Malinao, Albay & Agromet Station \\
\hline
\end{tabular}

\subsection{Suitability criteria}

\subsubsection{Suitable slope}

Suitable areas additional stations were within the 0 to 3 percent slope was considered generally flat areas (or leveled to nearly leveled areas). Analysis of the map shows that the flat areas of Southern Luzon were about 12654.25 square kilometers (4885.83 square miles), which represent 20.51 percent of the entire Southern Luzon area.

\subsubsection{Agricultural production areas}

There were 21 different classifications of land use and land cover for Southern Luzon. The removal of land cover, water bodies and swamps, cropland mixed with tall timber plantations, and other areas may interfere with the collection of weather data. Four classifications remained considered for the analysis. These were arable lands, cultivated areas, grassland, and other barren lands. Map analysis shows that agricultural production areas are equivalent to 44.23 percent of the total area of Southern Luzon. It constitutes 27282.36 square kilometers (10533.78 square miles).

\subsubsection{Categorized climate type}

According to Modified Corona Classification of Climate: Metro Manila, Laguna (except Eastern part), Batangas (except Eastern part), and Northwestern part of Palawan belongs to Type I climate while the Western part of Quezon Province and Bicol Region (except Western part) have Type II climate. Areas on Southern Luzon with Type III climate are eastern parts of Laguna and Batangas, Oriental Mindoro, Romblon, and Marinduque. The areas of Southern Luzon with Type IV climate are remaining areas of Quezon Province and the western part of Bicol Region (Bareja, 2011).

\subsubsection{Water bodies and coastlines}

The total area of water bodies found in Southern Luzon includes rivers, lakes, floodways, reservoirs, and wetlands, is 1442.53 square kilometers (556.96 square miles).

\subsection{Augmented Network of Station in Southern Luzon}

Table 3 shows the area as affected by individual factors and the reduction of the affected area by combination factors. Results show that only 8.57 percent (5288.90 square kilometers) of the total area of Southern Luzon remained considering the slope, agricultural production areas, water bodies and coastlines (outside $100 \mathrm{~m}$ buffer), and road network (inside $500 \mathrm{~m}$ buffer). The results show that 34 possible additional weather stations be installed based on the consideration of the remaining factors such as climate type, the minimum area of weather station, and availability of collaborating institutions.

Table 4 shows the list of the proposed additional weather stations in the area include: the collaborating institution, station type, and justification for the proposed supplemental stations. Results show that $79.41 \%$ (27 sites) of the proposed additional stations to be erected because their locations were outside the existing weather station radius of influence. The remaining stations are inside the actual weather station radius of influence but with different climate types. Hence, a need for a separate weather station due to climate variability. Some of the proposed stations have multiple possible locations due to the presence of numerous collaborating institutions. To avoid overlapping of the radius of influence, these were counted as one additional proposed station only due to their proximity with each other. For versatility purposes, the Agromet station is preferred over synoptic when the collaborating institutions were SUCs. Hence, all additional weather stations are classified as Agromet stations. The map of augmented agrometeorological station networks in Southern Luzon is shown in Figure 2. 
EPRA International Journal of Multidisciplinary Research (IJMR) - Peer Reviewed Journal

Volume: 7 | Issue: 2 | February 2021|| Journal DOI: 10.36713/epra2013 || SJIF Impact Factor 2021:7.147|| ISI Value: 1.188

Table 3. Area as affected by individual factor and reduction of area as affected by combination of factors

\begin{tabular}{|c|c|}
\hline Factors & $\begin{array}{c}\text { Area, } \\
\text { sq.m. }\end{array}$ \\
\hline Southern Luzon boundary & 61687.98 \\
\hline Slope & 12654.25 \\
\hline Agricultural production areas & 27282.36 \\
\hline Slope, Agricultural production areas & 5794.2 \\
\hline Slope, Agricultural production areas, water bodies & 5709.48 \\
\hline Slope, Agricultural production areas, water bodies and coastlines (outside & 5647.95 \\
\hline 100 m buffer), road buffer (500m) & 5288.9 \\
\hline
\end{tabular}


ISSN (Online): 2455-3662

EPRA International Journal of Multidisciplinary Research (IJMR) - Peer Reviewed Journal

Volume: 7 | Issue: 2 | February 2021|| Journal DOI: 10.36713/epra2013 || SJIF Impact Factor 2021:7.147|| ISI Value: 1.188

Table 4. Proposed additional weather station in Southern Luzon

\begin{tabular}{|c|c|c|c|c|c|}
\hline Station no. & Region & Location & Collaborating institution & Justification & Station type \\
\hline \multirow{2}{*}{$1^{*}$} & IV-A & Balayan, Batangas & Batangas State University-Balayan Campus & \multirow{2}{*}{ Outside existing weather station radius of influence } & Synoptic station \\
\hline & IV-A & San Juan, Batangas & Batangas State University-San Juan Campus & & Synoptic station \\
\hline 2 & IV-A & Nasugbu, Batangas & Batangas State University-Nasugbu Campus & Outside existing weather station radius of influence & Synoptic station \\
\hline 3 & IV-A & Tagkawayan, Quezon & $\begin{array}{l}\text { Southern Luzon State University-Tagkawayan } \\
\text { Campus }\end{array}$ & Outside existing weather station radius of influence & Synoptic station \\
\hline 4 & IV-A & Lucban, Quezon & Southern Luzon State University-Main Campus & $\begin{array}{l}\text { Inside existing weather station radius of influence but } \\
\text { with different climate type }\end{array}$ & Synoptic station \\
\hline 5 & IV-A & Mulanay, Quezon & $\begin{array}{l}\text { Polytechnic University of the Philippine- } \\
\text { Mulanay Campus }\end{array}$ & Outside existing weather station radius of influence & Synoptic station \\
\hline \multirow{2}{*}{$6^{*}$} & IV-B & Boac, Marinduque & Marinduque State College-Main Campus & \multirow{2}{*}{ Outside existing weather station radius of influence } & Synoptic station \\
\hline & IV-B & Gasan, Marinduque & Marinduque State College-Gasan Campus & & Synoptic station \\
\hline 7 & IV-B & $\begin{array}{l}\text { Mamburao, } \\
\text { Occidental Mindoro }\end{array}$ & $\begin{array}{l}\text { Occidental Mindoro State College-Mamburao } \\
\text { Campus }\end{array}$ & Outside existing weather station radius of influence & Synoptic station \\
\hline $8^{*}$ & IV-B & $\begin{array}{l}\text { Bongabong, Oriental } \\
\text { Mindoro }\end{array}$ & $\begin{array}{l}\text { Mindoro State College of Agriculture and } \\
\text { Technology- Bongabong Campus }\end{array}$ & Outside existing weather station radius of influence & Synoptic station \\
\hline 9 & IV-B & Cajidiocan, Romblon & Romblon State University-Cajidiocan Campus & Outside existing weather station radius of influence & Synoptic station \\
\hline 10 & IV-B & San Jose, Romblon & Romblon State University-San Jose Campus & Outside existing weather station radius of influence & Synoptic station \\
\hline 11 & IV-B & Sta. Fe, Romblon & Romblon State University-Sta Fe Campus & Outside existing weather station radius of influence & Synoptic station \\
\hline \multirow{5}{*}{$12^{*}$} & IV-B & $\begin{array}{l}\text { San Agustin, } \\
\text { Romblon }\end{array}$ & Romblon State University-San Agustin Campus & \multirow{5}{*}{ Outside existing weather station radius of influence } & Synoptic station \\
\hline & IV-B & San Andres, Romblon & Romblon State University-San Andres Campus & & Synoptic station \\
\hline & IV-B & Calatrave, Romblon & Romblon State University-Calatrava Campus & & Synoptic station \\
\hline & IV-B & Sta. Maria, Romblon & Romblon State University-Sta Maria Campus & & Synoptic station \\
\hline & IV-B & Odiongan, Romblon & Romblon State University-Main Campus & & Synoptic station \\
\hline 13 & IV-B & Taytay, Palawan & Palawan State University-Taytay Campus & Outside existing weather station radius of influence & Synoptic station \\
\hline $14^{*}$ & IV-B & $\begin{array}{l}\text { Rio Tuba, Bataraza, } \\
\text { Palawan }\end{array}$ & $\begin{array}{l}\text { Western Philippines University-Rio Tuba } \\
\text { Campus }\end{array}$ & Outside existing weather station radius of influence & Synoptic station \\
\hline
\end{tabular}

(C) 2021 EPRA IJMR | www.eprajournals.com | Journal DOI URL: https://doi.org/10.36713/epra2013 
ISSN (Online): 2455-3662

EPRA International Journal of Multidisciplinary Research (IJMR) - Peer Reviewed Journal

Volume: 7 | Issue: 2 | February 2021|| Journal DOI: 10.36713/epra2013 || SJIF Impact Factor 2021:7.147 || ISI Value: 1.188

\begin{tabular}{|c|c|c|c|c|c|}
\hline & IV-B & Bataraza, Palawan & Palawan State University-Bataraza Campus & & Synoptic station \\
\hline \multirow{2}{*}{$15^{*}$} & IV-B & Quezon, Palawan & Western Philippines University-Quezon Campus & \multirow{2}{*}{ Outside existing weather station radius of influence } & Synoptic station \\
\hline & IV-B & Quezon, Palawan & Palawan State University-Quezon Campus & & Synoptic station \\
\hline 16 & IV-B & Busuanga, Palawan & $\begin{array}{l}\text { Western Philippines University-Busuanga } \\
\text { Campus }\end{array}$ & Outside existing weather station radius of influence & Synoptic station \\
\hline 17 & IV-B & Dumaran, Palawan & Palawan State University-Dumaran Campus & Outside existing weather station radius of influence & Synoptic station \\
\hline 18 & IV-B & $\begin{array}{l}\text { Sablayan, Occidental } \\
\text { Mindoro }\end{array}$ & $\begin{array}{l}\text { Occidental Mindoro State College-Sablayan } \\
\text { Campus }\end{array}$ & Outside existing weather station radius of influence & Synoptic station \\
\hline 19 & IV-B & $\begin{array}{l}\text { Sofronio Española, } \\
\text { Palawan }\end{array}$ & $\begin{array}{l}\text { Palawan State University-Sofronio Española } \\
\text { Campus }\end{array}$ & Outside existing weather station radius of influence & Synoptic station \\
\hline 20 & IV-B & Rizal, Palawan & Palawan State University-Rizal Campus & Outside existing weather station radius of influence & Synoptic station \\
\hline 21 & IV-B & Roxas, Palawan & Palawan State University-Roxas Campus & Outside existing weather station radius of influence & Synoptic station \\
\hline 22 & IV-B & El Nido, Palawan & Palawan State University-El Nido Campus & Outside existing weather station radius of influence & Synoptic station \\
\hline 23 & IV-B & $\begin{array}{l}\text { Puerto Princesa, } \\
\text { Palawan }\end{array}$ & Palawan State University-Main Campus & Outside existing weather station radius of influence & Synoptic station \\
\hline 24 & IV-B & Culion, Palawan & $\begin{array}{l}\text { Western Philippines University-Culion } \\
\text { Campus }\end{array}$ & Outside existing weather station radius of influence & Synoptic station \\
\hline 25 & $\mathrm{~V}$ & $\begin{array}{l}\text { Jose Panganiban, } \\
\text { Camarines Norte }\end{array}$ & $\begin{array}{l}\text { Camarines Norte State College-Panganiban } \\
\text { Campus }\end{array}$ & Outside existing weather station radius of influence & Synoptic station \\
\hline 26 & V & Ragay, Camarines Sur & $\begin{array}{l}\text { Polytechnic University of the Philippines- } \\
\text { Ragay Campus }\end{array}$ & Outside existing weather station radius of influence & Synoptic station \\
\hline 27 & V & Goa, Camarines Sur & Partido State University-Main Campus & Outside existing weather station radius of influence & Synoptic station \\
\hline 28 & $\mathrm{~V}$ & $\begin{array}{l}\text { Pacasao, Camarines } \\
\text { Sur }\end{array}$ & $\begin{array}{l}\text { Central Bicol State University of Agriculture } \\
\text { Pacasao Campus }\end{array}$ & $\begin{array}{l}\text { Inside existing weather station radius of influence but } \\
\text { with different climate type }\end{array}$ & Synoptic station \\
\hline \multirow{2}{*}{$29 *$} & $\mathrm{~V}$ & Sagñay, Camarines Sur & Partido State University-Sagñay Campus & \multirow{2}{*}{$\begin{array}{l}\text { Inside existing weather station radius of influence but } \\
\text { with different climate type }\end{array}$} & Synoptic station \\
\hline & $\mathrm{V}$ & $\begin{array}{l}\text { Salogon San Jose, } \\
\text { Camarines Sur }\end{array}$ & Partido State University-Salogon Campus & & Synoptic station \\
\hline \multirow{2}{*}{$30 *$} & $\mathrm{~V}$ & $\begin{array}{l}\text { Calabanga, } \\
\text { Camarines Sur }\end{array}$ & $\begin{array}{l}\text { Central Bicol State University of Agriculture } \\
\text { Calabanga Campus }\end{array}$ & \multirow{2}{*}{$\begin{array}{l}\text { Inside existing weather station radius of influence but } \\
\text { with different climate type }\end{array}$} & Synoptic station \\
\hline & $\mathrm{V}$ & $\begin{array}{l}\text { San Jose, Camarines } \\
\text { Sur }\end{array}$ & Partido State University-San Jose Campus & & Synoptic station \\
\hline
\end{tabular}

(c) 2021 EPRA IJMR | www.eprajournals.com | Journal Dol URL: https://doi.org/10.36713/epra2013 
ISSN (Online): 2455-3662

EPRA International Journal of Multidisciplinary Research (IJMR) - Peer Reviewed Journal

Volume: 7 | Issue: 2 | February 2021|| Journal DOI: 10.36713/epra2013 || SJIF Impact Factor 2021:7.147 || ISI Value: 1.188

\begin{tabular}{|c|c|c|c|c|c|}
\hline 31 & $\mathrm{~V}$ & Magallanes, Sorsogon & Sorsogon State College-Magallanes Campus & $\begin{array}{l}\text { Inside existing weather station radius of influence but } \\
\text { with different climate type }\end{array}$ & Synoptic station \\
\hline \multirow[b]{2}{*}{$32^{*}$} & $\mathrm{~V}$ & Bulan, Sorsogon & Sorsogon State College-Bulan Campus & \multirow{2}{*}{$\begin{array}{l}\text { Inside existing weather station radius of influence but } \\
\text { with different climate type }\end{array}$} & Synoptic station \\
\hline & $\mathrm{V}$ & $\begin{array}{l}\text { Sorsogon City. } \\
\text { Sorsogon }\end{array}$ & Sorsogon State College-Main Campus & & Synoptic station \\
\hline 33 & $\mathrm{~V}$ & Castilla, Sorsogon & Sorsogon State College-Castilla Campus & $\begin{array}{l}\text { Inside existing weather station radius of influence but } \\
\text { with different climate type }\end{array}$ & Synoptic station \\
\hline 34 & $\mathrm{~V}$ & $\begin{array}{l}\text { Panganiban, } \\
\text { Catanduanes }\end{array}$ & $\begin{array}{l}\text { Catanduanes State University-Panganiban } \\
\text { Campus }\end{array}$ & Outside existing weather station radius of influence & Synoptic station \\
\hline
\end{tabular}

${ }^{*}$ additional stations with multiple available locations due to presence of numerous collaborating stations 


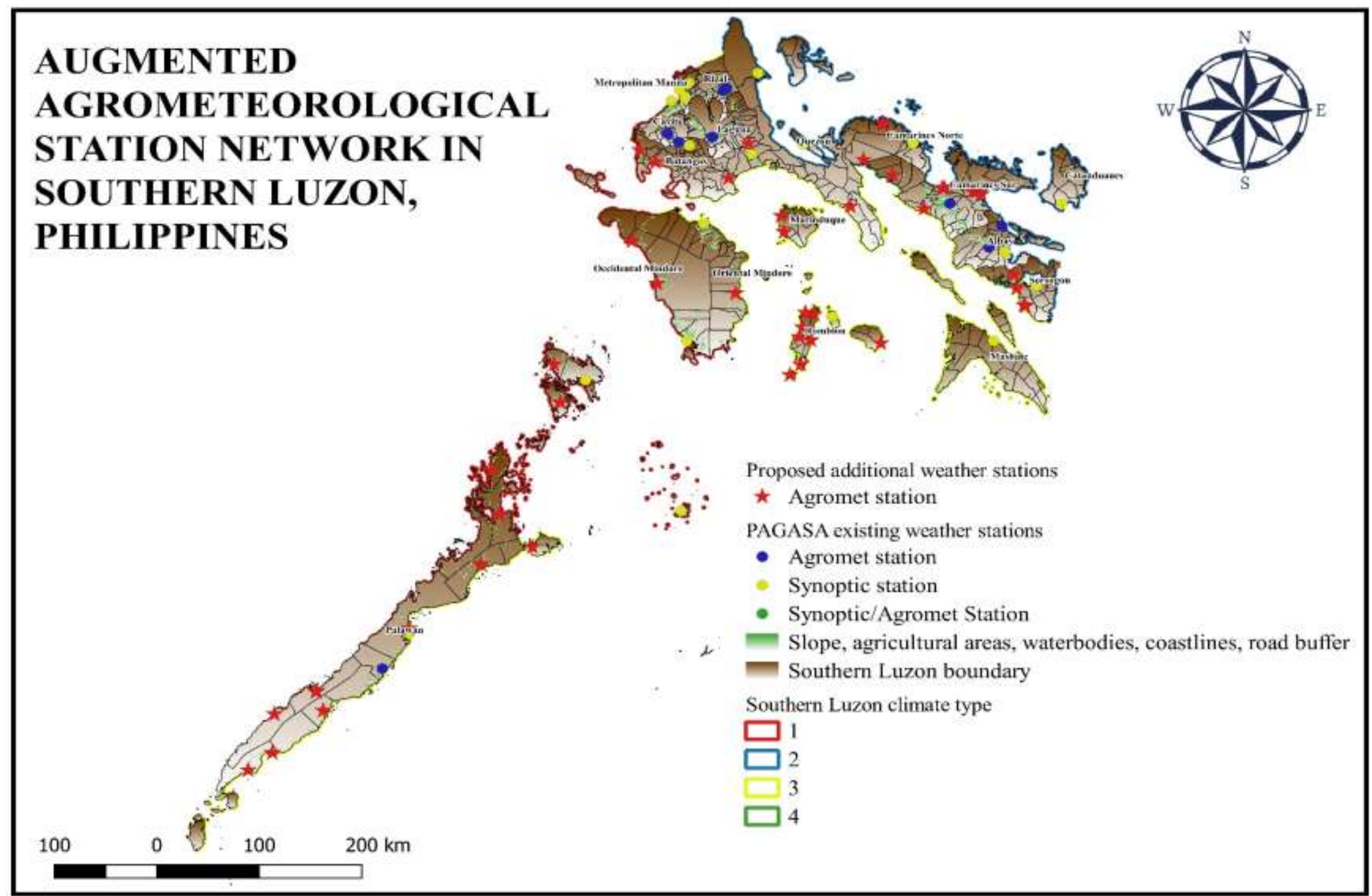

Figure 2. Augmented agrometeorological station network in Southern Luzon 


\section{CONCLUSION}

Weather stations are vital to performing network stations in providing data analyzing, relevant weather information, and forecasting. The Philippines has numerous weather station types such as Doppler radar, synoptic, and agrometeorological stations. However, the number of functional weather stations may not be enough to provide accurate weather data due to the climate and geographical variability of a specific region. To aid in better forecasting of climatic and weather conditions that affect agriculture in the country, locations of augmented agrometeorological stations in the Southern Luzon identified based on WMO guidelines. Only weather stations managed by PAGASA are involved in the analysis. AWS and project-based weather stations within the area are excluded because of the difficulties to access functionality and data availability. The primary considerations for selecting the locations were the admissible distance from existing weather stations, agricultural areas, climate type, slope, distance from water bodies, coastlines and roads, and possible collaborating institutions. The use of GIS map analysis conforming with all of the designed criteria gave 34 additional weather stations needed in the study area for augmented station networks. Therefore, with these stations added in the study area to the existing meteorological station, the weather information could be forecasted more accurately and more effectively.

\section{REFERENCES}

1. Alejo, L., 2018. Suitability analysis for optimum network of agrometeorological stations: A case study of Visayas Region, Philippines. Vol. 20, No. Journal of Agrometeorology 20 (4): 269-274.

2. Bareja, B.G. 2011. Climate Types in the Philippines, Annual Rainfall and Typhoon Frequency by Region. Retrieved on May 29, 2020 from

https://www.cropsreview.com/climatetypes.html

3. Bermudez, V.A., A.B.B. Abigos, D.C.N. Cuaresma, and J.F. Rabajante. 2017. Probability Distribution of Philippine Daily Rainfall Data. Retrieved on June 1, 2020 from https://www.preprints.org/manuscript/201712.01 50/v1/download

4. Gubler, S., Hunziker, S., Begert, M., Croci Maspoli, M., Konzelmann, T., Brönnimann, S., Schwierz, C., Oria, C.and Rosas, G. 2017. The Influence of Station Density on Climate Data Homogenization. Int. J. Climatol. 37(13):467083. Retrieved from https://rmets.onlinelibrary.wiley.com/doi/epdf/10. 1002/joc.5114.

5. Rana, A., 2012. Role of Remote Sensing and GIS in Agrometeorology. Retrieved from https://www.researchgate.net/publication/308749
358_Role_of_Remote_Sensing_and _GIS_in_Agrometeorology.

6. Sener E, Terzi O, Sener S et al. 2012. Modeling of water temperature based on GIS and ANN techniques: case study of Lake Egirdir (Turkey). Ekoloji 21(83): 44-52. Retrieved from http://www.ekolojidergisi.com/download/modelin g-of-water-temperature-based-ongis-and-anntechniques-case-study-of-lake-egirdir-turkey.pdf.

7. Tardin, R. 2013. System of open spaces. Retrieved on June 1, 2020 from https://books.google.com.ph/books?id=edxD2uar SksC\&pg $=P A 133 \& d q=i s+500+m+a$ ccesible + distance $\& h l=e n \& s a=X \& v e d=0 a h U K E$ wjIvNDwpeDpAhXMP3AKHcf7BBs Q6AEIKjAA\#v=onepage $\& q=i s \% 20500 \% 20 \mathrm{~m} \% 2$ Oaccesible\%20distance $\& f=$ false

8. World Meteorological Organization (WMO). 2010. Guide to Agricultural Meteorological Practices. WMO-No. 134. WMO, Geneva, Switzerland. 